Jurnal Selulosa Vol. 8 No. 1 Juni 2018 Hal. 9 - 20

\title{
Pemanfaatan Lumpur Primer Industri Kertas sebagai Absorben
}

\author{
Krisna Adhitya Wardhana*, Saepulloh, Reynaldo Biantoro \\ Balai Besar Pulp dan Kertas, Jl. Raya Dayeuhkolot No 132 Bandung, Indonesia
}

Diterima : 14 November 2017, Revisi akhir : 03 Mei 2018, Disetujui terbit : 07 Mei 2018

The Utilization of Primary Sludge from Paper Mills as Absorbent

\begin{abstract}
The primary sludge from paper mill contains cellulose fiber that has high absorption capacity and potential to be used as an absorbent for hydrophobic compounds. The utilization of primary sludge from paper mill using raw material of waste paper and virgin pulp to be used as an absorbent has been conducted. The stages process of absorbent fabrication consisted of three stages such as drying, mechanical and chemical processes. Mechanical process conducted were crushing and grinding methods to increase surface area and pore volume of sludge. Meanwhile, silanization process as chemical treatment using solution of $\gamma$-metacryloxypropyl trimethoxysilane in ethanol to improve the hydrophobic properties of primary sludge was also done. Absorbent products were tested for the maximum sorbency, the sorbent performance, absorption of hydrophobic liquid, absorption of hydrophobic dust, and contact angle test to conduct their performance. The absorbency of absorbent product which is covered by cushion material was also tested. The results indicated that the absorption performance of some absorbent product is higher than commercial absorbent on hydrophobic liquid and hydrophobic dust absorption test. However, it was lower than commercial absorbent on maximum sorbency and the sorbent performance test. The use of cushion material as a wrapper could make it easy in the collection and could increase the absorbency.
\end{abstract}

Keywords: primary sludge, mechanical treatment, silanization, absorbent, hydrophobic

\begin{abstract}
Abstrak
Lumpur primer dari industri kertas mengandung serat selulosa yang memiliki daya serap tinggi dan memiliki potensi dimanfaatkan sebagai absorben senyawa hidrofobik. Pemanfaatan lumpur primer industri kertas berbahan baku kertas bekas dan virgin pulp sebagai absorben telah dilakukan. Tahapan proses pembuatan absorben dari lumpur primer meliputi proses pengeringan, proses mekanis, dan proses kimia. Proses mekanis yang dilakukan adalah crushing dan grinding untuk meningkatkan luas permukaan dan volume pori-pori lumpur dilanjutkan dengan proses silanisasi (silanization) sebagai perlakuan kimia menggunakan larutan $\gamma$-metacryloxypropyl trimethoxysilane dalam etanol untuk meningkatkan sifat hidrofobik lumpur. Produk absorben diuji daya serap maksimum (maximum sorbency), kinerja absorben, penyerapan cairan hidrofobik, penyerapan debu hidrofobik, dan pengujian sudut kontak. Daya serap produk absorben yang ditutup bahan bahan cushion juga diuji. Hasil menunjukkan kemampuan absorbsi cairan hidrofobik dan debu hidrofobik dari beberapa perlakuan produk absorben lebih tinggi dari absorben komersial, sedangkan hasil maximum sorbency dan uji kinerja absorben menunjukkan hasil lebih rendah dari absorben komersial. Penggunaan bahan cushion sebagai pembungkus dapat memudahkan dalam pengumpulan dan dapat meningkatkan penyerapan.
\end{abstract}

Kata kunci: lumpur primer, perlakuan mekanis, silanisasi, absorben, hidrofobik 


\section{Pendahuluan}

Pengolahan air limbah di Instalasi Pengolahan Air Limbah (IPAL) menghasilkan polutan yang terpisahkan dan membentuk lumpur yang perlu dikelola dengan baik. Pengelolaan lumpur IPAL dilakukan berdasarkan prinsip reuse, recycle, dan recovery sebelum dibuang di landfill. Pada industri kertas dengan produksi riil sebesar 8,21 juta ton/ tahun akan menghasilkan sludge sebesar 0,25 juta ton/tahun - 0,33 juta ton/tahun atau sekitar 800 ton/hari -1000 ton/hari (Hardiani dan Masriani, 2015). Salah satu cara pengelolaan lumpur IPAL diantaranya adalah dengan memanfaatkannya sebagai absorben. Absorben adalah material yang memiliki kemampuan untuk menyerap zat lain. Material yang digunakan sebagai absorben harus memiliki kapasitas serap yang tinggi terhadap material hidrofobik dan memiliki berat jenis yang lebih rendah dari pada air (Likon et al., 2011).

Lumpur primer dihasilkan dari proses sedimentasi tetapi dapat juga dihasilkan dariproses flotasi seperti Dissolved Air Flotation (DAF). Kadar padatan di dalam lumpur primer berkisar antara 1,5\% - 6,5\% tergantung karakteristik materialnya (Scott et al., 1995). Selain itu karakteristik lumpur juga dipengaruhi oleh bahan baku ataupun proses yang terjadi. Pabrik kertas berbahan baku serat bekas menghasilkan lumpur yang lebih banyak dibandingkan dengan pabrik berbahan baku kayu (Monte et al., 2009). Hagelqvist (2013) melaporkan bahwa lumpur primer biasanya lebih mudah mengalami proses pengurangan kadar air (dewatering) dibandingkan dengan lumpur biologi.

Selulosa merupakan bahan terbarukan dan merupakan salah satu bahan organik yang paling melimpah keberadaannya di alam ini. Material ini cenderung bersifat tidak larut dan banyak digunakan untuk bahan pembuatan kertas. Secara alami selulosa memiliki kemampuan absorbsi yang rendah tetapi dengan adanya modifikasi dapat memperbaiki sifat itu (Bergh, 2011). Pemanfaatan selulosa dalam bentuk selulosa nanofiber yang berhasil diisolasi dari kayu ataupun hasil samping pertanian menjadi aerogel hidrofobik dilakukan oleh Aguilar et al. (2016) yang kemudian menggunakan produknya untuk menyerap minyak

Perlu diingat juga bahwa selulosa yang terkandung dalam lumpur primer merupakan bahan yang memiliki daya serap tinggi. Likon et al. (2011) menjelaskan bahwa lumpur
IPAL industri kertas mengandung 75\% - 99\% serat dan $1 \%-25 \%$ bahan pengisi (filler) anorganik. Bahan yang mengandung selulosa memiliki daya serap tinggi dan dapat digunakan sebagai penyerap (absorben) seperti untuk menyerap tumpahan minyak atau oli (Monte et al., 2009) baik pada permukaan tanah atau di permukaan air. Absorben dari material yang mengandung serat selulosa memiliki kemampuan yang mirip dengan absorben yang terbuat dari polimer sintetis (polipropilen) bila digunakan untuk menyerap tumpahan minyak pada permukaan air (Payne et al., 2012). Lebih lanjut Hubbe et al. (2014) menjelaskan bahwa absorben dari serat selulosa memiliki kelebihan dibandingkan absorben dari polimer sintetis karena lebih mudah untuk terdegradasi secara alami bila ada absorben tersebut yang tidak terambil sehingga terlepas ke dalam perairan pada saat atau setelah digunakan.

Proses mekanis merupakan salah satu tahap penyiapan absorben untuk meningkatkan luas permukaan lumpur. Dengan peningkatan luas permukaan material, maka kemampuan menyerap senyawa yang diinginkan akan semakin maksimal. Guzzo et. al. (2014) menyebutkan bahwa proses pemotongan (crushing) dan penumbukan (grinding) diperlukan untuk mendapatkan ukuran partikel yang kecil. Proses crushing akan menghasilkan agregat halus dengan distribusi ukuran yang berbeda, cenderung lebih kaku dengan permukaan yang lebih kasar (Cepuritis et al., 2014). Sementara proses grinding akan mengubah material, tidak hanya dengan menyebabkan partikel terfragmen dan mengubah luas permukaan spesifik, tetapi juga memodifikasi distribusi ukuran pori dan perubahan strukturnya seperti transformasi polimorfik, microstrains (Garcia et al., 1991). Dalam proses mekanis ini, waktu perlakuan harus sangat diperhatikan. Guzzo, et al. (2014) menyebutkan bahwa waktu grinding yang terlalu lama juga dapat merusak bahan.

Proses silanisasi (silanization) merupakan perlakuan kimia untuk meningkatkan sifat hidrofobik lumpur. Silanisasi merupakan proses pelapisan permukaan suatu materi melalui proses self-assembly dengan molekul alkoksisilan organofungsional. Proses silanisasi bertujuan untukmeningkatkan sifathidrofob (hidrofobisitas) dari suatu materi (Seed, 2001). Material organik yang mengandung gugus hidroksil seperti selulosa dapat dimodifikasi sifatnya melalui proses silanisasi. Beberapa senyawa silan yang 
telah digunakan untuk proses silanisasi serat selulosa diantaranya 3-(trimethoxysilyl) propyl methacrylate (TMS), dichlorodimethylsilane (DDS) dan trichlorovinylsilane (TVS) (Vázquez dan García, 2010). Nader dan Cordova (2011) berhasil membuat material penolak air dari selulosa yang dimodifikasi dengan alkiltrialkoksisilan. Untuk absorben, Likon et al. (2011) menggunakan $\gamma$-metacryloxypropyl trimethoxysilane dalam memodifikasi selulosa yang terkandung dalam lumpur IPAL.

Dalam makalah ini diuraikan proses pembuatan absorben dari lumpur primer dengan perlakuan mekanis crushing dan grinding dan perlakuan kimia dengan proses silanisasi. Pengaruh dari masing-masing perlakuan terhadap kualitas daya serap absorben terhadap minyak, oli, cairan hidrofobik dan debu hidrofobik dibahas dalam makalah ini.

\section{Bahan dan Metode}

\section{Bahan}

Lumpur yang digunakan adalah lumpur primer dari IPAL industri kertas berbahan baku kertas bekas (Lumpur A) dan industri kertas dengan bahan baku virgin pulp (Lumpur B). Bahan kimia yang digunakan untuk proses silanisasi adalah $\gamma$-metacryloxypropyl trimethoxysilane dan etanol sebagai pelarut. Senyawa hidrofobik yang hendak dihilangkan diwakili oleh minyak kelapa (m) dan oli yang digunakan SAE 20W50 dengan spesifikasi kinematic viscosity pada $40^{\circ} \mathrm{C}$ $185,91 \mathrm{cSt}$ dan $100^{\circ} \mathrm{C} 19,95 \mathrm{cSt}$ (o). Biosolar dan fly ash dari pabrik tekstil digunakan untuk pengujian debu hidrofobik. Kemudian bahan cushion absorben terbuat dari kertas kraft yang diputihkan tanpa menggunakan senyawa klorin.

\section{Metode}

Secara umum metode penelitian yang dilakukan mengacu pada Likon et al. (2011) dengan beberapa modifikasi. Tahapan kegiatan terdiri dari:

\section{Karakterisasi lumpur primer}

Lumpur primer dianalisis kandungan air, senyawa organik (selulosa), kadar abu, berat jenis, serta uji morfologi serat untuk mengetahui potensinya sebagai absorben. Pelaksanaan uji karakterisasi lumpur primer dilakukan di Laboratorium Sarana Riset Pulp, Kertas, dan Derivat Selulosa BBPK dan Pusat Penelitian dan Pengembangan Sumber Daya Air Kementerian Pekerjaan Umum.

\section{Pembuatan absorben}

Pembuatan absorben dari lumpur primer meliputi 2 tahapan utama berikut:

a. Preparasi lumpur meliputi proses pengeringan dengan diangin-anginkan dan dilanjutkan perlakuan mekanis. Pengeringan dilakukan untuk mendapatkan kadar air $\pm 30 \%$. Lumpur yang sudah dikeringkan kemudian diberi variasi perlakuan mekanis crushing dan grinding dengan menggunakan alu lumpang, ball mill dan wiley mill untuk melihat pengaruhnya terhadap morfologi serat lumpur yang dihasilkan. Untuk melihat pengaruh perlakuan mekanis terhadap lumpur dilakukan pengujian luas permukaan dengan metode Multi Point BET (1), BJH method cumulative adsorption surface area (2), BJH method cumulative desorption surface area (3), DH method cumulative adsorption surface area (4), DH method cumulative desorption surface area (5), dan DFT cumulative surface area (6). Volume pori lumpur terdiri dari 7 metode yaitu BJH method cumulative adsorption pore volume (1), BJH method cumulative desorption pore volume(2), DH method cumulative adsorption pore volume (3), DH method cumulative desorption pore volume(4), HK method micropore volume(5), $S F$ method micropore volume (6), dan DFT method cumulative pore volume (7). Metode yang digunakan untuk pengukuran pori adalah Average Pore Radius (1), BJH Method adsorption pore Radius (2), BJH method desorption pore Radius (3), DH method adsorption pore Radius (4), DH method desorption pore Radius (5), HK method pore Radius (6), dan SF method pore Radius (7).

b. Proses silanisasi(silanization) dilakukan dengan menggunakan larutan $\gamma$-metacryloxypropyl trimethoxysilane 5\% dalam etanol $95 \%$. Larutan tersebut disemprotkan secara homogen menggunakan sprayer pada lumpur yang telah mengalami perlakuan mekanis dengan perbandingan antara larutan silan dan lumpur 1:20. Campuran tersebut selanjutnya dipanaskan di dalam oven pada suhu $80^{\circ} \mathrm{C}$ 
selama 30 menit dan kemudian suhu dinaikkan $10^{\circ} \mathrm{C}$ setiap jam sampai mencapai suhu $130^{\circ} \mathrm{C}$.

Lumpur primer yang telah mendapatkan perlakuan mekanis dan kimia dikarakterisasi untuk melihat pengaruh kedua metode perlakuan terhadap sifat lumpur primer. Karakterisasi meliputi pengukuran sudut kontak, pengukuran luas permukaan, ukuran dan distribusi pori-pori lumpur, pengukuran SEM (Scanning Electron Microscope), dan pengukuran dengan FTIR (Fourier Transform Infra Red).

\section{Pengujian absorben}

Pengujian daya absorbsi absorben dilakukan melalui pengujian maximum sorbency, pengujian kinerja absorben, terhadap larutan hidrofobik dan terhadap debu hidrofobik seperti abu batubara. Pengujian dilakukan mengacu pada Likon et al., (2011) dengan modifikasi. Pengujian daya serap absorben komersial juga dilakukan sebagai pembanding.

\section{a. Pengujian daya absorbsi maksimum (maximum sorbency) \\ Pengujian maximum sorbency dilakukan} untuk mengetahui kuantitas minyak atau oli yang dapat diikat pada permukaan absorben. Absorben dengan berat tertentu dimasukkan ke dalam 10 g minyak atau oli pada suhu ruang. Setelah 24 jam, absorben yang telah jenuh dipindahkan pada cawan petri dan kemudian ditekan dengan anak timbang seberat $1 \mathrm{~kg}$ selama 2 jam. Setelah itu absorben dikeringkan menggunakan oven pada suhu $105^{\circ} \mathrm{C}$ sampai beratnya konstan. Perbedaan berat antara absorben jenuh dan absorben awal dianggap sebagai keefektifan penyerapan.

\section{b. Pengujian kinerja absorben}

Pengujian ini dilakukan untuk mengetahui kinerja absorben dengan mengacu pada Likon et al. (2011) dengan modifikasi.

c. Pengujian dengan menggunakan cairan hidrofobik

Sebanyak $800 \mathrm{~mL}$ air dimasukkan ke dalam gelas piala $1000 \mathrm{~mL}$. Minyak dan oli dalam jumlah tertentu diteteskan ke dalamnya sehingga membentuk titik-titik (spot) minyak. Tambahkan absorben dengan jumlah tertentu sampai airnya jernih. Absorben yang telah menyerap kemudian dipisahkan dan dikeringkan di dalam oven pada suhu $105^{\circ} \mathrm{C}$ hingga beratnya konstan. Selisih antara berat akhir absorben dengan berat awal menunjukkan efektivitas absorbsi.

d. Pengujian dengan menggunakan debu hidrofobik

Pengujian dengan menggunakan debu hidrofobik memiliki prinsip kerja yang sama dengan pengujian menggunakan cairan hidrofobik, perbedaannya hanya pada materi uji yang digunakan. Pada uji dengan debu hidrofobik digunakan debu fly ash yang dicampur dengan biosolar dengan perbandingan 1:1.

\section{e. Pengujian dengan menggunakan absorbent} cushion.

Prinsip pengujiannya sama dengan menggunakan cairan hidrofobik, hanya absorben yang digunakan dikemas dalam bentuk bantalan berukuran $4 \mathrm{~cm} \times 3 \mathrm{~cm}$ dengan bahan pembungkus (cushion) untuk mengetahui pengaruh cushion dalam membantu penyerapan.

\section{Hasil dan Pembahasan}

\section{Karakteristik lumpur primer IPAL}

Hasil karakterisasi lumpur primer indutri kertas baik yang berbahan baku kertas bekas maupun yang berbahan baku virgin pulp sebagaimana ditunjukkan pada Tabel 1. Kadar abu lumpur primer yang berasal dari virgin pulp lebih tinggi dibandingkan lumpur primer yang berasal dari kertas bekas. Kadar abu ini, terutama yang berasal dari industri kertas berbahan baku virgin pulp tidak berbeda dengan nilai kadar abu lumpur primer industri kertas yang disampaikan Ochoa de Alda (2008) yang berkisar 51\% - 58\%. Adanya proses fiber recovery yang cukup efektif pada industri kertas berbahan baku virgin pulp dapat menjadi penyebab tingginya kadar abu lumpur primer. Dengan adanya fiber recovery,

Tabel 1. Data Hasil Karakterisasi Lumpur Primer IPAL Industri Kertas

\begin{tabular}{llccc}
\hline No & Parameter & Satuan & $\begin{array}{c}\text { Lumpur } \\
\text { A }\end{array}$ & $\begin{array}{c}\text { Lumpur } \\
\text { B }\end{array}$ \\
\hline 1 & Kadar air & $\%$ & 4,66 & 13,52 \\
2 & Kadar organik & $\%$ & 57,44 & 35,22 \\
3 & Kadar abu & $\%$ & 37,91 & 51,26 \\
4 & Specific gravity & - & 1,43 & 1,92 \\
\hline
\end{tabular}


serat-serat dapat digunakan kembali sehingga terjadi efisiensi bahan baku. Serat yang terbawa air limbah masuk ke IPAL memiliki kandungan organik yang sudah makin berkurang. Sementara akumulasi bahan-bahan anorganik yang berasal dari bahan kimia dapat meningkatkan kandungan unsur anorganik lumpur yang terdeteksi sebagai kadar abu. Hal ini sesuai dengan pernyataan Ochoa de Alda (2008) yang menyebutkan bahwa kadar abu yang tinggi dapat berasal dari bahan pengisi (filler) yang digunakan dalam proses pembuatan kertas. Kadar abu yang tinggi cenderung membuat bahan menjadi lebih berat. Data spesific gravity lumpur juga menunjukkan bahwa lumpur memiliki berat jenis di atas berat jenis air sehingga cenderung akan tenggelam. Selain itu, seiring dengan tingginya kadar abu, lumpur B memiliki berat jenis yang lebih besar dari lumpur $\mathrm{A}$.

Dari hasil uji morfologi serat (Gambar 1) dapat dilihat bahwa lumpur primer memiliki banyak pengotor yang berwarna kehitaman yang berada disekeliling serat selulosa. Pengotor tersebut bisa berupa bahan kimia yang digunakan dalam proses pembuatan kertas maupun bahan kimia yang digunakan dalam proses pengolahan air limbah. Hal serupa juga terlihat dari hasil analisis SEM pada Gambar 2. Hal ini sesuai dengan pernyataan Bajpai (2015) yang menyatakan bahwa lumpur primer sebagian besar terdiri dari serat dan filler. Adanya pengotor dapat mengganggu terjadinya reaksi antara selulosa dengan bahan kimia dalam proses silanisasi.
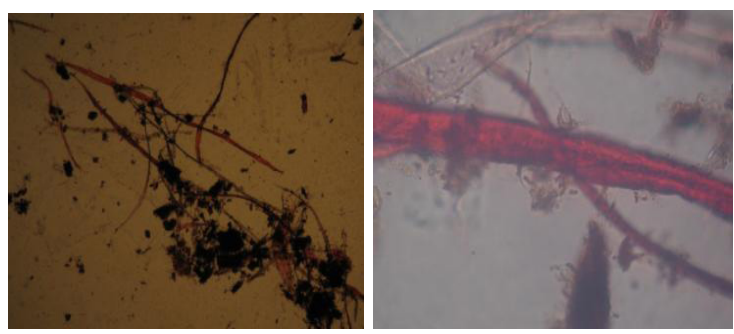

(a)
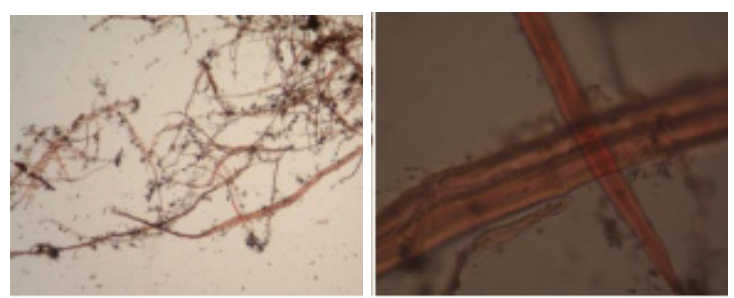

(b)

Gambar 1. Morfologi Serat (a) Lumpur A dan (b) Lumpur B

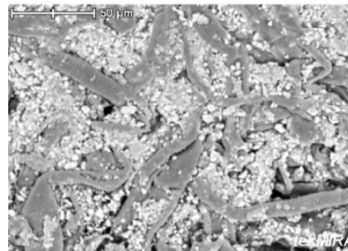

(a)

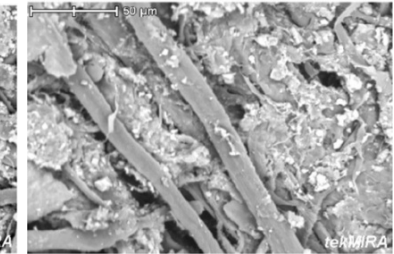

(b)
Gambar 2. Hasil Analisis SEM (a) Lumpur Primer B dan (b) Lumpur Primer A

Proses fiber recovery yang dilakukan dalam rangka efisiensi penggunaan serat cukup berpengaruh terhadap morfologi lumpur primer. Proses fiber recovery yang efektif menyebabkan hanya serat berukuran pendek dan butiran halus yang terbawa air limbah ke dalam IPAL. Hasil uji morfologi serat pada Tabel 2 menunjukkan bahwa serat selulosa lumpur B memiliki panjang serat yang lebih pendek dibandingkan lumpur A. Selain itu, distribusi serat lumpur B memiliki komposisi serat dengan ukuran yang lebih pendek dari lumpur A.

\section{Pembuatan absorben}

Proses pengeringan lumpur primer bertujuan untuk mendapatkan kadar air berkisar $\pm 30 \%$ dengan bantuan panas sinar matahari dan kemudian dilanjutkan dengan proses mekanis. Tujuan utama dari proses mekanis ini adalah meningkatkan luas permukaan lumpur untuk memperbanyak kontak material dengan senyawa hidrofobik sehingga peluang terjadinya absorbsi akan semakin besar walaupun masih mempertimbangkan faktor-faktor yang lain seperti ukuran pori.

Dari Tabel 2 dapat dilihat bahwa adanya proses mekanis akan mengurangi panjang serat yang ada pada lumpur dan juga meningkatkan persentase fines yang ada. Pengurangan panjang serat tersebut terjadi karena adanya proses crushing dan grinding yang menumbuk dan menggiling serat yang ada dalam lumpur. Hasil proses crushing dan grinding tadi akan terdeteksi sebagai serat halus dengan ukuran yang lebih kecil. Persentase distribusi serat juga bergeser menjadi lebih kecil dan didominasi ukuran $0,2 \mathrm{~mm}-1 \mathrm{~mm}$.

Hasil pengujian luas permukaan (Tabel 3) menunjukkan bahwa terjadi peningkatan luas permukaan material lumpur dibandingkan pada kondisi sebelum perlakuan mekanis. Hal ini 
Tabel 2. Morfologi Serat Lumpur Primer

\begin{tabular}{|c|c|c|c|c|c|c|c|}
\hline \multirow[b]{2}{*}{ No } & \multirow[b]{2}{*}{ Sampel } & \multirow{2}{*}{$\begin{array}{l}\text { Diameter } \\
(\mu \mathrm{m})\end{array}$} & \multirow{2}{*}{$\begin{array}{c}\text { Panjang } \\
\text { serat }(\mathrm{mm})\end{array}$} & \multirow{2}{*}{$\begin{array}{c}\text { Fines } \\
(\%)\end{array}$} & \multicolumn{3}{|c|}{ Distribusi serat (\%) } \\
\hline & & & & & $0,2-1,0 \mathrm{~mm}$ & $1,0-3,0 \mathrm{~mm}$ & $3,0-7,5 \mathrm{~mm}$ \\
\hline 1 & Lumpur A awal & 25,50 & 1,611 & 7,30 & 43,00 & 44,90 & 12,00 \\
\hline 2 & Lumpur A crushing & 27,70 & 0,908 & 16,50 & 76,00 & 18,90 & 5,10 \\
\hline 3 & Lumpur A grinding & 25,90 & 1,000 & 10,40 & 71,20 & 23,60 & 5,20 \\
\hline 4 & Lumpur B awal & 18,90 & 0,787 & 10,80 & 85,60 & 11,50 & 2,90 \\
\hline 5 & Lumpur B crushing & 19,20 & 0,607 & 18,40 & 92,50 & 6,70 & 0,80 \\
\hline 6 & Lumpur B grinding & 18,70 & 0,549 & 17,30 & 94,90 & 5,00 & 1,00 \\
\hline
\end{tabular}

Tabel 3. Luas Permukaan Lumpur Primer sebelum dan setelah Perlakuan Mekanis

\begin{tabular}{lccccccc}
\hline & \multicolumn{7}{c}{ Luas permukaan $\left(\mathrm{m}^{2} / \mathrm{g}\right)$} \\
\cline { 2 - 6 } Metode & \multicolumn{5}{c}{ Lumpur B } & \\
\cline { 2 - 6 } & $\begin{array}{c}\text { Lumpur } \\
\text { awal }\end{array}$ & $\begin{array}{c}\text { Setelah } \\
\text { crushing }\end{array}$ & $\begin{array}{c}\text { Setelah } \\
\text { grinding }\end{array}$ & $\begin{array}{c}\text { Lumpur } \\
\text { awal }\end{array}$ & $\begin{array}{c}\text { Setelah } \\
\text { crushing }\end{array}$ & $\begin{array}{c}\text { Setelah } \\
\text { grinding }\end{array}$ & Komersial \\
\hline 1 & 0,128 & 4,160 & 1,330 & 2,494 & 1,798 & 4,466 & 4,998 \\
2 & 0,698 & 2,702 & 0,6442 & 1,575 & 1,616 & 2,908 & 2,247 \\
3 & 1,360 & 3,985 & 0,8977 & 2,573 & 3,110 & 4,703 & 3,305 \\
4 & 0,703 & 2,777 & 0,6743 & 1,595 & 1,661 & 2,967 & 2,315 \\
5 & 1,381 & 4,053 & 0,9096 & 2,618 & 3,165 & 4,794 & 3,397 \\
6 & 1,662 & 3,422 & 0,8404 & 2,143 & 2,885 & 3,399 & 2,847 \\
\hline
\end{tabular}

Tabel 4. Volume Pori Lumpur Primer sebelum dan setelah Perlakuan Mekanis

\begin{tabular}{|c|c|c|c|c|c|c|c|}
\hline \multirow{3}{*}{ Metode } & \multicolumn{7}{|c|}{ Volume pori $(\mathrm{mL} / \mathrm{g})$} \\
\hline & \multicolumn{3}{|c|}{ Lumpur A } & \multicolumn{3}{|c|}{ Lumpur B } & \multirow[b]{2}{*}{ Komersial } \\
\hline & $\begin{array}{c}\text { Lumpur } \\
\text { awal }\end{array}$ & $\begin{array}{l}\text { Setelah } \\
\text { crushing }\end{array}$ & $\begin{array}{l}\text { Setelah } \\
\text { grinding }\end{array}$ & $\begin{array}{c}\text { Lumpur } \\
\text { awal }\end{array}$ & $\begin{array}{l}\text { Setelah } \\
\text { crushing }\end{array}$ & $\begin{array}{l}\text { Setelah } \\
\text { grinding }\end{array}$ & \\
\hline 1 & 0,0137 & 0,0189 & 0,0097 & 0,01800 & 0,0196 & 0,0190 & 0,0045 \\
\hline 2 & 0,0129 & 0,0182 & 0,0097 & 0,01820 & 0,0185 & 0,0193 & 0,0051 \\
\hline 3 & 0,0132 & 0,0184 & 0,0094 & 0,01740 & 0,0190 & 0,0185 & 0,0050 \\
\hline 4 & 0,0125 & 0,0177 & 0,0094 & 0,01770 & 0,0181 & 0,0188 & 0,0050 \\
\hline 5 & - & 0,0014 & - & 0,00110 & 0,0009 & 0,0017 & 0,0013 \\
\hline 6 & 0,1947 & 0,0006 & 0,0002 & 0,00075 & 0,0005 & 6,8260 & 0,0003 \\
\hline 7 & 0,0046 & 0,0144 & 0,0046 & 0,01330 & 0,0146 & 0,0139 & 0,0060 \\
\hline
\end{tabular}

terjadi karena dalam perlakuan mekanis, lumpur direduksi ukurannya menjadi lebih kecil dengan cara ditumbuk ataupun digiling menjadi material dengan kuantitas satuan yang lebih banyak sehingga akan memperbesar luas permukaan material dalam berat yang sama.

Pengujian terhadap volume pori lumpur dan ukuran pori juga dilakukan dalam rangka melihat pengaruh perlakuan mekanis terhadap perubahan volume dan ukuran pori lumpur primer. Volume pori dan ukuran pori yang semakin besar akan memudahkan senyawa hidrofobik tersebut untuk diserap oleh absorben. Hasil pengujian volume pori lumpur primer (Tabel 4) menunjukkan bahwa secara umum terjadi peningkatan volume pori setelah perlakuan mekanis. Adanya peningkatan volume pori tersebut akan memperbesar kemungkinan senyawa hidrofobik untuk diabsorb oleh absorben.

Hasil pengujian ukuran pori menunjukkan hasil yang sedikit berbeda untuk dua jenis lumpur yang digunakan, lumpurprimerAmenunjukkan sebagian 
Tabel 5. Ukuran Pori Lumpur Primer sebelum dan setelah Perlakuan Mekanis

\begin{tabular}{lccccccc}
\hline & \multicolumn{7}{c}{ Ukuran pori $(\AA)$} \\
\cline { 2 - 6 } Metode & \multicolumn{5}{c}{ Lumpur A } & \multicolumn{5}{c}{ Lumpur B } & \\
\cline { 2 - 7 } & $\begin{array}{c}\text { Lumpur } \\
\text { awal }\end{array}$ & $\begin{array}{c}\text { Setelah } \\
\text { crushing }\end{array}$ & $\begin{array}{c}\text { Setelah } \\
\text { grinding }\end{array}$ & $\begin{array}{c}\text { Lumpur } \\
\text { awal }\end{array}$ & $\begin{array}{c}\text { Setelah } \\
\text { crushing }\end{array}$ & $\begin{array}{c}\text { Setelah } \\
\text { grinding }\end{array}$ & Komersial \\
\hline 1 & 1410 & 93,93 & 139,9 & 146,4 & 211,4 & 88,67 & 24,67 \\
2 & 470,5 & 19,18 & 63,71 & 61,77 & 21,86 & 17,18 & 15,42 \\
3 & 162,5 & 17,12 & 150,2 & 85,81 & 17,03 & 17,06 & 17,02 \\
4 & 470,5 & 19,18 & 21,86 & 61,77 & 21,86 & 17,18 & 15,42 \\
5 & 162,5 & 17,12 & 150,2 & 85,81 & 17,03 & 17,06 & 17,02 \\
6 & 1,562 & 1,838 & 9,337 & 1,838 & 1,838 & 7,812 & 7,187 \\
7 & 9,551 & 2,261 & 17,21 & 2,261 & 18,92 & 1,754 & 1,754 \\
\hline
\end{tabular}

besar terjadi penurunan ukuran pori setelah proses mekanis baik proses crushing maupun grinding, sementara lumpur primer B juga menunjukkan kecenderungan yang sama setelah proses crushing maupun grinding. Hal ini dapat disebabkan oleh kandungan abu yang ada pada lumpur primer $\mathrm{A}$ dan B. Unsur anorganik yang diwakili oleh kadar abu berperan sebagai titik absorbsi atau titik masuknya senyawa hidrofobik ke dalam lumpur. Kadar abu dapat terlepas atau berkurang selama proses penggilingan atau penumbukan. Hilangnya kadar abu yang ada dapat mengurangi ukuran pori yang ada. Visualisasi SEM hasil proses mekanis dapat dilihat pada Gambar 3. Proses silanisasi dilakukan dengan tujuan untuk membuat lumpur primer yang telah mengalami proses mekanis menjadi lebih bersifat hidrofobik. Secara teoritis akan terjadi perubahan gugus fungsi - $\mathrm{OH}$

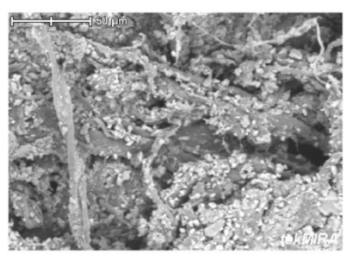

(a)

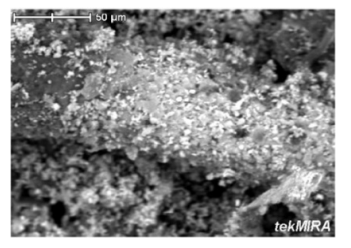

(b)

Gambar 3. Hasil SEM (a) Lumpur B Crushing, (b) Lumpur B Grinding, (c) Lumpur A Crushing, (d) Lumpur A Grinding pada serat selulosa menjadi gugus lain yang bersifat lebih hidrofobik. Keberhasilan proses silanization dapat diketahui melalui pengujian daya serap produk hasil proses silanisasi terhadap cairan hidrofobik maupun melalui pengujian dengan FTIR.

Berdasarkan data pada Gambar 4 dapat diketahui bahwa tidak ada perbedaan yang nyata antara spektrum FTIR lumpur sebelum dan sesudah proses silanisasi baik untuk lumpur A maupun B. Keberhasilan proses silanisasi ditunjukkan oleh adanya peningkatan yang kuat pada bilangan gelombang $1750 \mathrm{~cm}^{-1}$ (regangan gugus karbonil, $\mathrm{mC}=\mathrm{O}$ ), $1241 \mathrm{~cm}^{-1}$ (regangan $\mathrm{C}-\mathrm{O}$ dari gugus asetat), $604 \mathrm{~cm}^{-1}$ (adanya gugus metil dari senyawa alkoksisilan), dan pada bilangan gelombang $2942 \mathrm{~cm}^{-1}, 1376 \mathrm{~cm}^{-1}$ dan $900 \mathrm{~cm}^{-1}$ (regangan gugus metal dari gugus asetil) serta adanya puncak pada bilangan gelombang $1152 \mathrm{~cm}^{-1}$ dan $1154 \mathrm{~cm}^{-1}$ dari regangan simetrik $\mathrm{C}-\mathrm{O}-\mathrm{Si}$ yang menunjukkan adanya ikatan kimia antara serat selulosa dengan senyawa alkoksisilan (Vázquez dan García, 2010).

Meskipun hasil pengukuran dengan FTIR tidak menunjukkannya adanya reaksi antara serat selulosa dengan $\gamma$-metacryloxypropyl trimethoxysilane, proses silanisasi tetap memberikan efek yang positif terhadap kinerja absorben. Tabel $\mathbf{6}$ menunjukkan pengaruh penambahan $\gamma$-metacryloxypropyl trimethoxysilane pada dosis yang berbeda-beda terhadap maximum sorbency lumpur. Semakin tinggi dosis $\gamma$-metacryloxypropyl trimethoxysilane yang digunakan akan berpengaruh terhadap semakin tingginya nilai maximum sorbency dari lumpur. Hal itu dapat terjadi karena meskipun proses silanization belum berhasil, adanya 


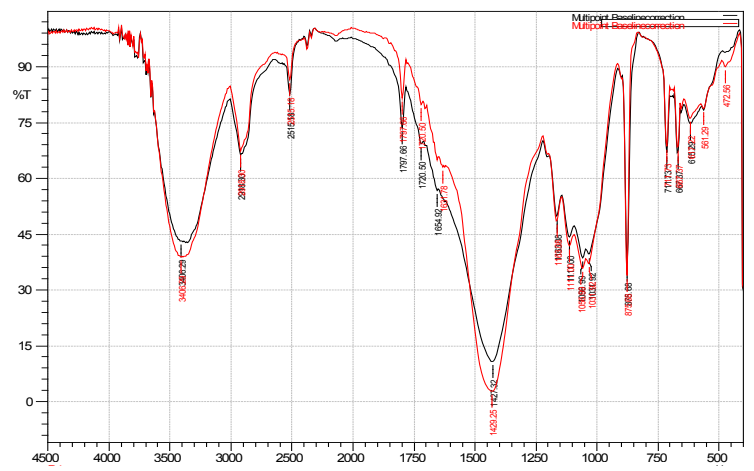

(a)

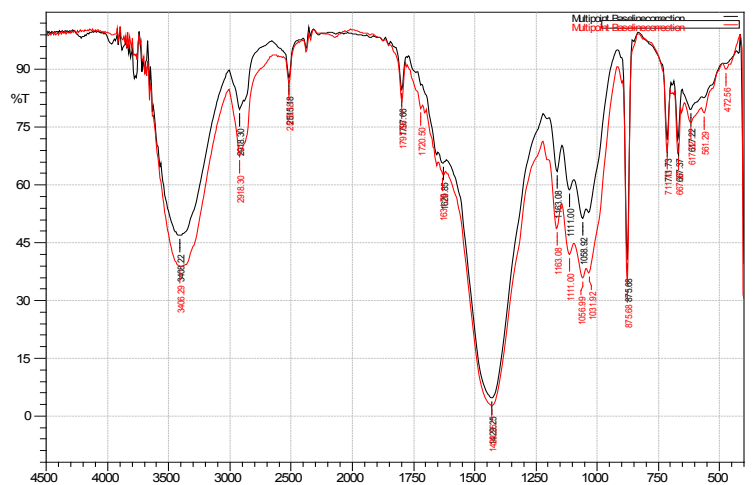

(b)

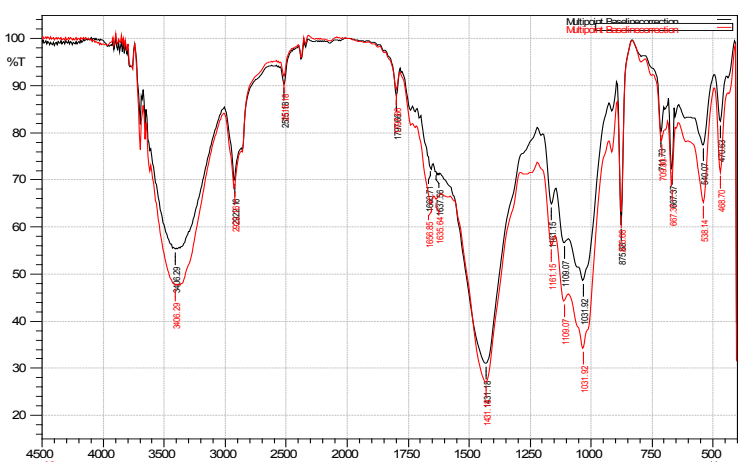

(c)

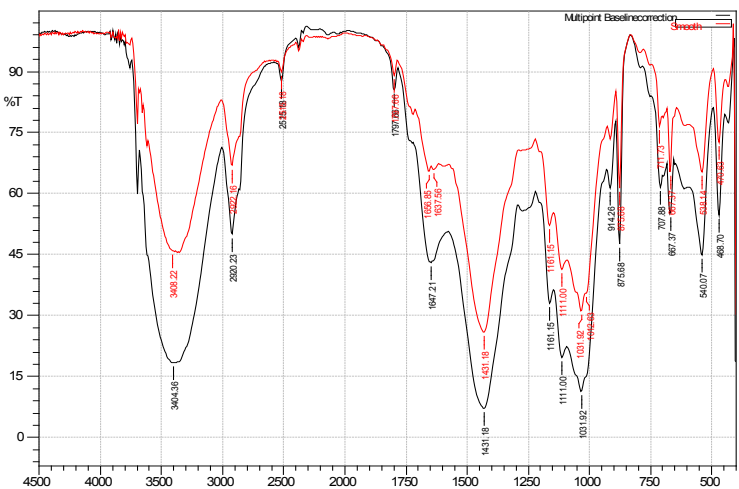

(d)

Gambar 4. Spektrum FTIR Tumpang Tindih (Over Lay) antara Lumpur Sebelum dan Sesudah Proses Silanisasi. Absorben Lumpur A Crushing (a) dan Grinding (b) serta Absorben Lumpur B Crushing (c) dan Grinding (d)

$\gamma$-metacryloxypropyl trimethoxysilane yang menempel pada permukaan serat mengakibatkan terjadinya perubahan sifat serat yang secara tidak langsung mempengaruhi daya serap maksimumnya.

\section{Uji coba absorben}

Hasil uji maximum sorbency dapat dilihat pada Gambar 5a. Perlakuan mekanis (crushing dan grinding) memberikan peningkatan maximum sorbency yang signifikan ketika diujicobakan ke minyak dan oli. Besar persentase peningkatan untuk absorben dari lumpur A, yaitu $20 \%$ dan $89 \%$ untuk proses crushing serta sebesar $227 \%$ dan $170 \%$ untuk proses grinding. Sementara untuk absorben dari lumpur B, kenaikan nilai maximum sorbency oli dan minyak setelah proses crushing adalah sebesar $80 \%$ dan $135 \%$ serta sebesar $303 \%$ dan $452 \%$ untuk proses grinding. Hal ini sesuai dengan hasil penelitian Likon et al. (2011) yang menyebutkan bahwa tahap perlakuan mekanis merupakan tahap yang paling penting dalam pembuatan absorben. Perlakuan kimia dengan proses silanisasi kurang signifikan dalam meningkatkan nilai maximum sorbency. Pada lumpur A, proses silanisasi mampu memberikan kenaikan maximum sorbency minyak dan oli pada lumpur crushing sebesar $30 \%$ dan $55 \%$, sementara pada lumpur grinding

Tabel 6. Perbandingan Dosis Silanisasi

\begin{tabular}{lcc}
\hline $\begin{array}{l}\text { Dosis } \\
\text { (larutan silan: } \\
\text { lumpur) }\end{array}$ & $\begin{array}{c}\text { Konsentrasi } \\
\text { larutan silan } \\
(\%)\end{array}$ & $\begin{array}{c}\text { Max. sorbency } \\
\text { (g minyak/ } \\
\text { g absorben) }\end{array}$ \\
\hline & 5 & 5,35 \\
& 20 & 5,79 \\
& 30 & 5,93 \\
$1: 10$ & 40 & 5,92 \\
& 50 & 5,93 \\
& 60 & 6,26 \\
& 80 & 6,34 \\
\hline
\end{tabular}




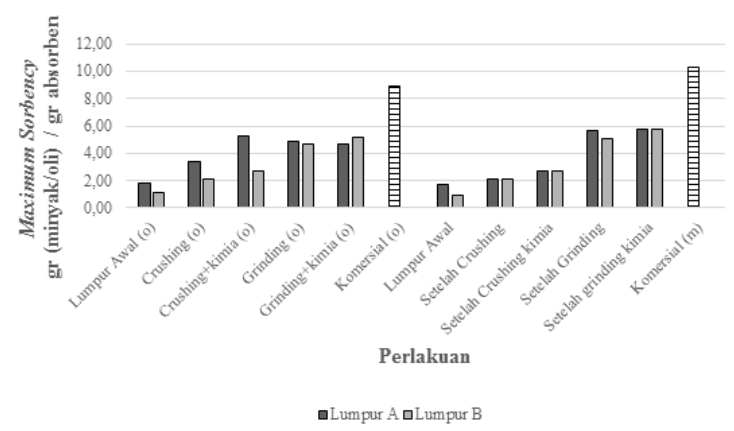

(a)

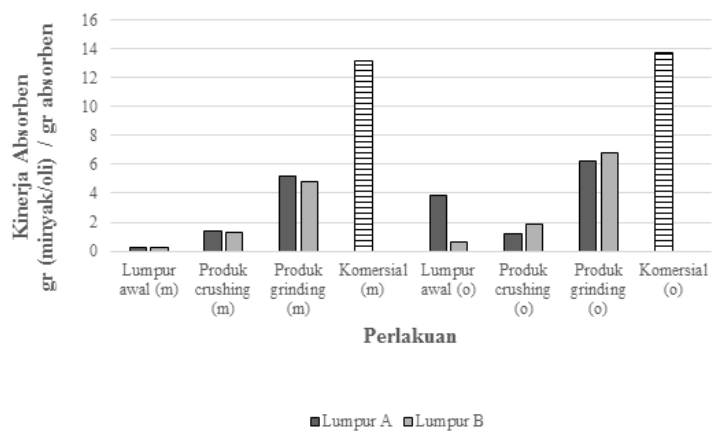

(b)

Gambar 5. Hasil Uji (a) Maximum Sorbency (b) Uji Kinerja Absorben terhadap Minyak (m) dan Oli (o)

kenaikan maximum sorbency minyak sebesar 1\% dan tidak ada kenaikan untuk oli. Pada lumpur B proses silanisasi lumpur crushing menghasilkan kenaikan maximum sorbency oli dan minyak sebesar $31 \%$ dan $24 \%$, sedangkan silanisasi pada lumpur grinding memberikan kenaikan sebesar $10 \%$ dan 14\%. Dari hasil uji maximum sorbency absorben komersial lebih tinggi dibandingkan absorben hasil penelitian ini (Gambar 5a).

Hasil pengujian kinerja absorben pada minyak goreng $(\mathrm{m})$ dan oli (o) dapat dilihat pada Gambar 5b. Secara umum, absorben dari proses grinding menunjukkan kinerja yang lebih baik dibandingkan produk dari proses crushing. Luas permukaan yang didukung dengan ukuran pori yang semakin besar akan meningkatkan kemampuan absorbsi material. Bila dibandingkan dengan absorben komersial, kinerja absorben produk dari penelitian ini menunjukkan hasil yang lebih rendah.

Pengujianterhadapcairanhidrofobik dilakukan untuk melihat kemampuan absorben dalam menyerap senyawa hidrofobik yang tercampur dengan air di perairan. Kemampuan absorben untuk menyeleksi antara air atau senyawa hidrofobik yang diserap sangat diperlukan.

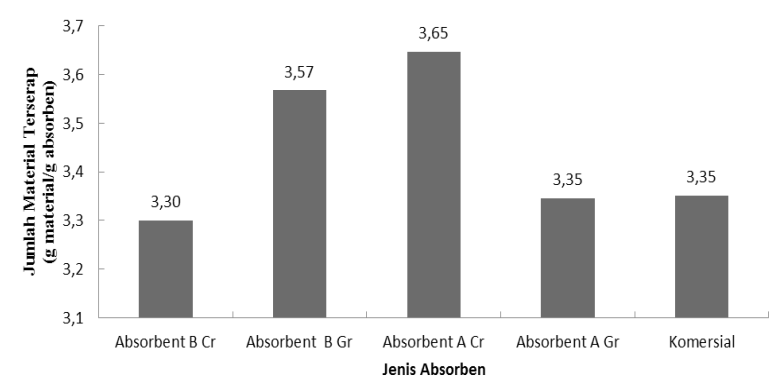

(a)

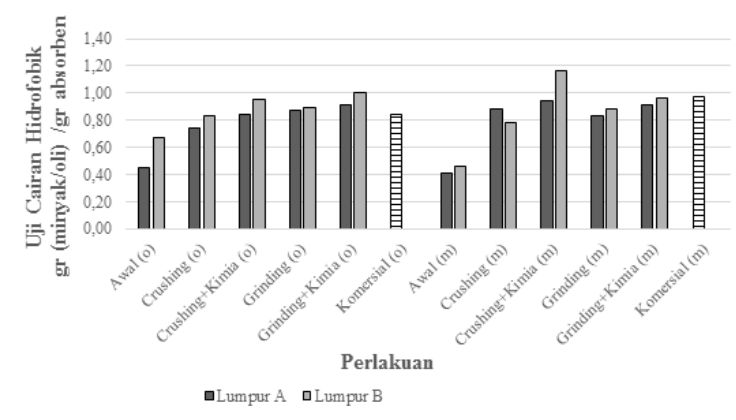

(b)

Gambar 6. Pengujian dengan menggunakan (a) Cairan Hidrofobik (b) Debu Hidrofobik

Hasil pengujian terhadap cairan hidrofobik dapat dilihat pada Gambar 6b. Perlakuan mekanis dan perlakuan kimia memberikan peningkatan kemampuan menyerap dari lumpur terhadap cairan hidrofobik.

Proses mekanis crushing (Cr) dan grinding (Gr) meningkatkan kemampuan absorbsi dari lumpur A dan lumpur B. Pada lumpur A perlakuan crushing meningkatkan kemampuan absorbsi oli dan minyak sebesar $63 \%$ dan $113 \%$ serta lumpur B sebesar $24 \%$ dan $69 \%$. Perlakuan grinding meningkatkan kemampuan absorbsi oli dan minyak lumpur A sebesar $93 \%$ dan $102 \%$ serta lumpur B sebesar 33\% dan 90\%. Proses silanisasi juga memberikan kenaikan terhadap kemampuan absorbsi lumpur yang telah mengalami proses crushing dan grinding. Pada lumpur A perlakuan silanisasi terhadap lumpur crushing menyebabkan kenaikan absorbsi oli dan minyak sebesar $14 \%$ dan $7 \%$ serta pada lumpur B sebesar $14 \%$ dan $48 \%$. Perlakuan silanisasi terhadap lumpur grinding juga meningkatkan absorbsi oli dan minyak lumpur A sebesar 4\% dan 10\% serta pada lumpur B sebesar $13 \%$ dan $17 \%$. Produk absorben berbasis crushing memiliki kemampuan hampir setara dengan absorben komersial, bahkan produk absorben 
dari lumpur B dapat melebihi absorben komersial dalam menyerap minyak dan oli. Absorben berbasis grinding juga menunjukkan hasil yang baik. Kedua produk absorben dari 2 jenis lumpur grinding menunjukkan kinerja yang melebihi produk komersial dalam menyerap oli. Hal ini dapat dipengaruhi oleh struktur absorben yang ada. Produk absorben berbasis grinding memiliki luas permukaan yang lebih besar dibandingkan dengan crushing. Dengan luas permukaan yang lebih besar, kemungkinan terjadinya kontak dengan senyawa hidrofobik juga semakin besar. Setiap absorben memiliki daya serap yang berbeda untuk setiap jenis senyawa hidrofobik. Secara umum produk absorben yang dihasilkan dari lumpur primer industri kertas dengan bahan baku virgin pulp menunjukkan kinerja yang lebih baik dibandingkan dengan bahan baku kertas bekas.

Pengujian menggunakan debu hidrofobik dari fly ash yang dicampur dengan biosolar dengan perbandingan 1:1 disajikan pada Gambar 6a. Hasil menunjukkan bahwa produk absorben dari lumpur A crushing memiliki kemampuan menyerap yang paling tinggi. Produk absorben yang dihasilkan memiliki performa yang lebih tinggi dari absorben komersial. Hal ini sejalan dengan hasil dari uji terhadap cairan hidrofobik.

Ada hal yang berbeda diantara hasil uji maximum sorbency, pengujian kinerja absorben dan uji terhadap cairan hidrofobik. Pada uji maximum sorbency dan pengujian kinerja absorben, performa produk absorben lebih rendah dibandingkan dengan produk absorben komersial akan tetapi pada uji dengan senyawa hidrofobik, beberapa perlakuan produk absorben yang dihasilkan menunjukkan performa yang lebih tinggi dari pada absorben komersial. Hal tersebut dapat dijelaskan sebagai berikut; dalam uji maximum sorbency, absorben dikontakkan dengan senyawa hidrofobik (oli atau minyak goreng) saja tanpa keberadaan air sehingga tidak terjadi proses seleksi. Pada pengujian dengan cairan hidrofobik, senyawa hidrofobik yang akan dihilangkan bercampur dengan air sehingga terjadi proses seleksi dalam memilih air atau senyawa hidrofobik yang diserap. Hal ini menunjukkan bahwa produk absorben yang dihasilkan memiliki kemampuan selektif yang lebih baik. Selain itu, diperkuat dengan hasil pengujian sudut kontak dan visualisasinya pada Gambar 7. Pada pengujian sudut kontak, secara teoretis sudut di atas $90^{\circ}$ menunjukkan sifat hidrofobik suatu bahan. Absorben dari proses crushing dan absorben dari proses grinding menunjukkan adanya peningkatan nilai sudut kontak dibandingkan lumpur awal. Nilai sudut kontak produk absorben memiliki nilai yang lebih besar dibandingkan absorben komersial. Hal ini menandakan bahwa produk absorben lebih bersifat hidrofobik daripada produk komersial.

Penggunaan bahan cushion dilakukan untuk memudahkan pengumpulan dan mengurangi terjadinya kekeruhan. Produk absorben dikemas menggunakan bahan cushion dan kemudian diuji dengan mekanisme yang sama dengan uji terhadap cairan hidrofobik. Hasil uji penyerapan minyak (m) dan oli (o) oleh produk absorben, bahan cushion dan total penyerapan ditunjukkan
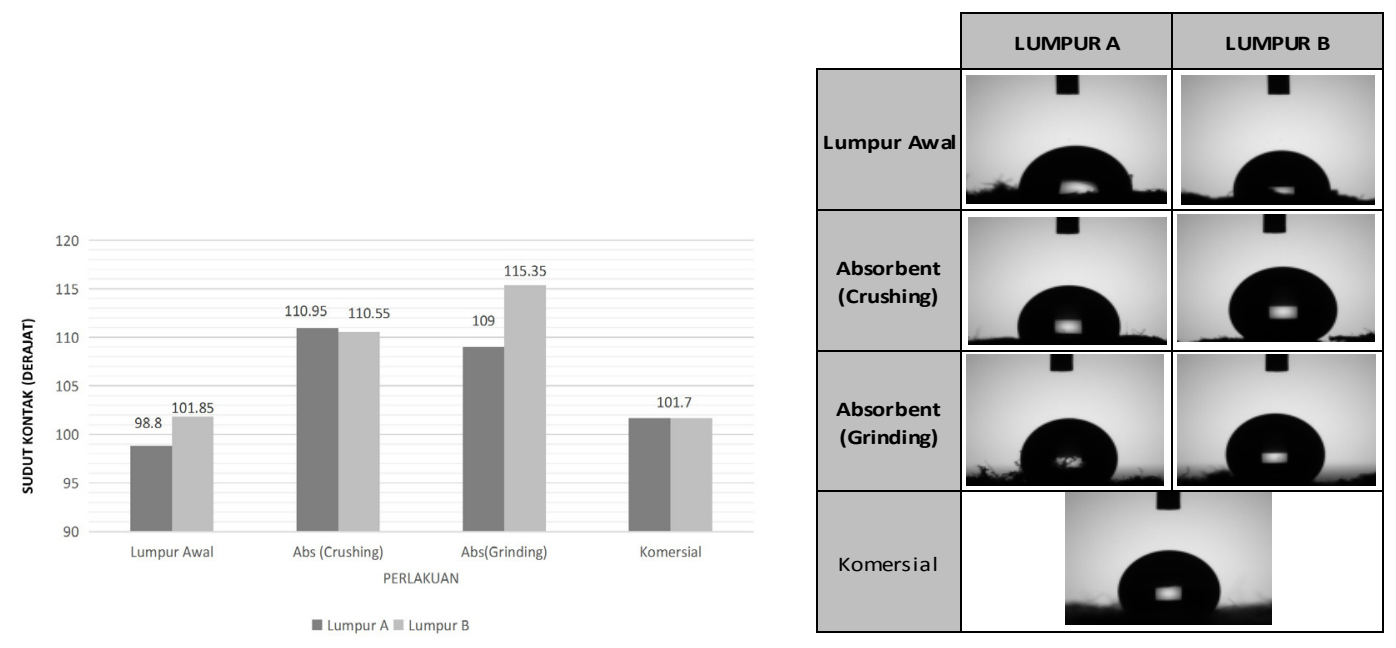

Gambar 7. Sudut Kontak 


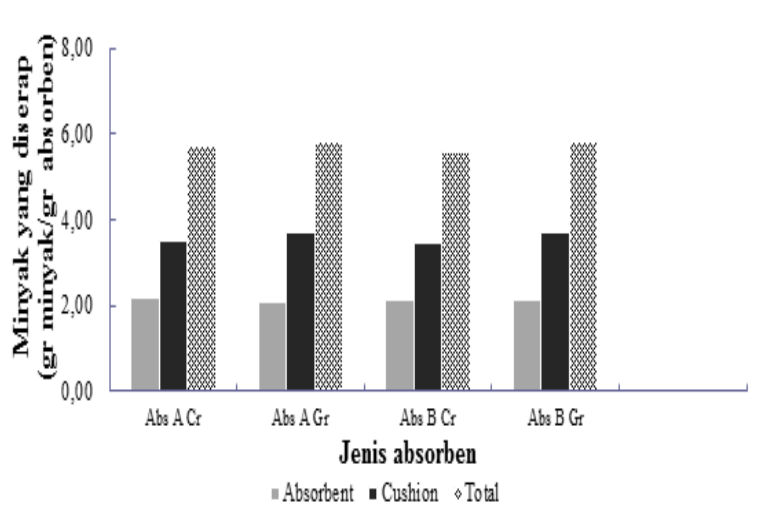

(a)

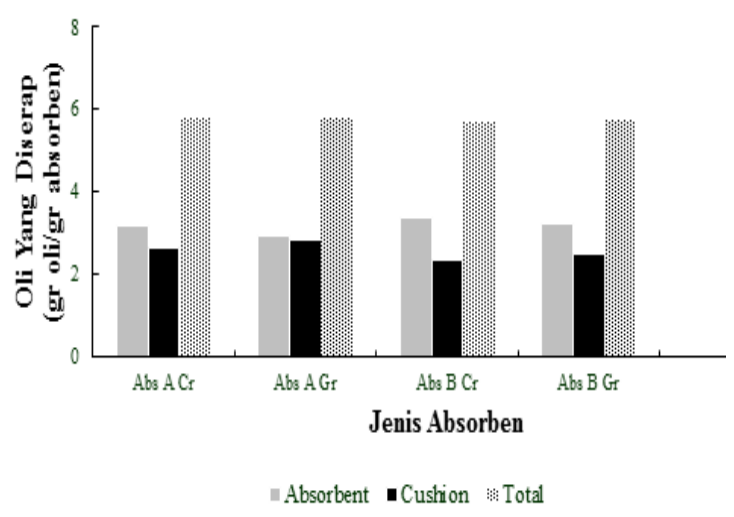

(b)

Gambar 8. Penyerapan (a) Minyak (b) Oli oleh Absorben dan Bahan Cushion

pada Gambar 8. Hasil menunjukkan bahwa pemakaian bahan cushion dapat meningkatkan kemampuan penyerapan senyawa hidrofobik (minyak goreng dan oli) oleh semua produk absorben. Dengan demikian pemakaian bahan cushion selain mempermudah pengumpulan juga dapat meningkatkan penyerapan.

\section{Kesimpulan}

Lumpur primer industri kertas yang berbahan baku virgin pulp dan kertas bekas dapat dimanfaatkan sebagai absorben untuk menyerap senyawa hidrofobiksepertiminyakdan oli. Proses mekanis dan kimia diperlukan untuk mengubah lumpur primer agar dapat dimanfaatkan sebagai absorben. Perlakuan mekanis (crushing dan grinding) yang memperbesar luas permukaan dan ukuran pori lumpur memberikan efek yang lebih signifikan dalam peningkatan daya serap lumpur dibandingkan dengan perlakuan kimia dengan proses silanisasi (silanization). Berdasarkan uji yang dilakukan, secara umum proses mekanis grinding memberikan efek yang cenderung lebih baik dalam peningkatan kemampuan absorbsi lumpur dibandingkan dengan proses crushing. Kemampuan absorbsi cairan hidrofobik dan debu hidrofobik dari beberapa perlakuan produk absorben lebih tinggi dari absorben komersial. Namun hasil maximum sorbency dan uji kinerja absorben menunjukkan hasil lebih rendah dari absorben komersial. Peningkatan kualitas produk absorben berbasis lumpur primer industri kertas perlu diteliti lebih lanjut untuk mendapatkan kemampuan penyerapan yang maksimal.

\section{Ucapan Terima Kasih}

Penulis mengucapkan terima kasih yang sebesar besarnya kepada Sri Purwati, Henggar Hardiani, Kristaufan Joko Pramono, Prima Besty Asthary, Toni Rachmanto dan semua anggota tim atas bantuan dan masukannya selama pelaksanaan penelitian.

\section{Daftar Pustaka}

Aguilar, M. D., Gonzalez, I., Jimenez, A.M., Tarres, Q., Quintana, G., dan Mutje, P. (2016). Cellulose Nano Fibers Modified with Alkyl Ketene Dimer for Oil Absorbent Aerogels. Cellulose Chem.Technology 50 (3-4), 369-375

Bajpai, P. (2015) 'Management of pulp and paper mill waste', in Management of Pulp and Paper Mill Waste, pp. 1-197. doi: 10.1007/978-3-319-11788-1.

Cepuritis, R. et al. (2014) 'Filler from Crushed Aggregate for Concrete: Pore Structure, Specific Surface, Particle Shape and Size Distribution', Cement and Concrete Composites. Elsevier Ltd, 54, pp. 2-16. doi: 10.1016/j.cemconcomp.2014.03.010.

Garcia, F. G., Abrio, M. T. R. and Rodriguez, M. G. (1991) 'Effects of dry grinding on two kaolins of different degrees of crystallinity', Clay Minerals, 26, pp. 549-565.

Guzzo, P. L., Santos, J. B. and David, R. C. (2014) 'Particle Size Distribution and Structural Changes in Limestone Ground in Planetary Ball Mill', International Journal of Mineral Processing. Elsevier B.V., 126, pp. 41-48. doi: 10.1016/j.minpro.2013.11.005. 
Hagelqvist, A. (2013) Sludge from Pulp and Paper Mills for Biogas Production, Dissertation. Karlstad University Studies.

Hardiani, H., Masriani, R. (2015) Potensi Sludge dari Industri Kertas sebagai Bahan Baku Chipboard. Jurnal Riset Teknologi Industri. Vol. 9, No. 1, Hal. 1-12.

Hubbe, M. A., Park, J. and Park, S. (2014) 'Cellulosic substrates for removal of pollutants from aqueous systems: A review. Part 4. Dissolved petrochemical compounds', BioResources, pp. 7782-7925. doi: 10.15376/biores.8.2.3038-3097.

Likon, M. et al. (2011) 'Papermill industrial waste as a sustainable source for high efficiency absorbent production', Waste Management, 31(6), pp. 1350-1356. doi: 10.1016/j. wasman.2011.01.012.

Monte, M. C. et al. (2009) 'Waste management from pulp and paper production in the European Union.', Waste management (New York, N.Y.). Elsevier Ltd, 29(1), pp. 293-308. doi: 10.1016/j. wasman.2008.02.002.
Ochoa de Alda, J. A. G. (2008) 'Feasibility of recycling pulp and paper mill sludge in the paper and board industries', Resources, Conservation and Recycling, 52(7), pp. 965972. doi: 10.1016/j.resconrec.2008.02.005.

Payne, K. C. et al. (2012) 'Oil spills abatement: Factors affecting oil uptake by cellulosic fibers', Environmental Science and Technology, 46(14), pp. 7725-7730. doi: 10.1021/es3015524.

Seed, B. (2001) 'Silanizing Glassware', Current Protocols in Cell Biology, (8:3E:A.3E.1A.3E.2). doi: 10.1002/0471143030. cba03es08.

Vázquez, N. A. R. and García, T. L. (2010) 'Spectroscopy Analysis of Chemical Modification of Cellulose Fibers', Journal of the Mexican Chemical Society, 54(4), pp. 192-197. 